\title{
Low Prevalence of Obesity and Pattern of Food Habits among Nepalese Medical Students
}

\author{
Prem Prasad Panta ${ }^{1}$, Kapil Amgain², Deepak Sharma ${ }^{3}$, Nirmala Chapagain ${ }^{4}$, Phanindra Kafle ${ }^{5}$
}

\section{Author Info:}

\section{${ }^{1}$ Associate Professor,}

${ }^{2}$ Assistant Professor; Karnali Academy Health Sciences, Jumla

${ }^{3}$ University of New South Wales, Sydney, Australia

${ }^{4}$ Lecturer, Nepal Institute of Health Sciences, Kathmandu, Nepal

${ }^{5}$ Assistant, Professor, Nepal Medical College, Kathmandu, Nepal

\section{Corresponding Author: \\ Prem Prasad Panta \\ Email/Contact:} pantaprem7@gmail.com

\section{ABSTRACT}

Background: Overweight and obesity are major risk factors for non-communicable diseases (NCDs) like diabetes, cardiovascular diseases, musculoskeletal disorders, including cancer. The risk of NCDs increases, with increases of body mass index (BMI). Food choices and eating habits have been changed according to the pace of development and urbanization. Such a nutritional transition has been claimed for increasing rates of overweight and obesity which are recently observed in our adolescent and youths. Adolescents and youths are vulnerable groups of the development of overweight and obesity. Therefore, the objective of this study was to determine the prevalence of obesity and the associated food pattern among Nepalese medical students.

Methods: A cross-sectional study was conducted on 170 medical students of Nepal Medical College of 17 to 26 years in December 2018 using a self-administered questionnaire to assess the pattern of eating habit and prevalence of overweight and obesity by using BMI classification. Data were analyzed using SPSS statistical software, and the Chi-square test was used to establish the relationship of variables.

Results: The study showed that $7.1 \%$ of the participants were overweight and obese with average BMI of $21.46 \pm 2.74$. Three-fourth $(72.4 \%)$ of the participants reported taking meals regularly. Two third of the participants (65.9\%) reported that they consume vegetables and the vast majority $(83.5 \%)$ had eaten fruits at least a day. Less than half of the students (44.1\%) were found to be alcohol users whereas consumption of smoking was not common (1.2\%). Demographic variables such as the income of the family and ethnicity were significantly associated with $\mathrm{BMI}(P<.05)$.

Conclusion: The prevalence of obesity was found to be low in comparison to the national scenario as the healthy food habits were predominant among the medical students.

Keywords: Eating habit, Medical students, Obesity, Overweight

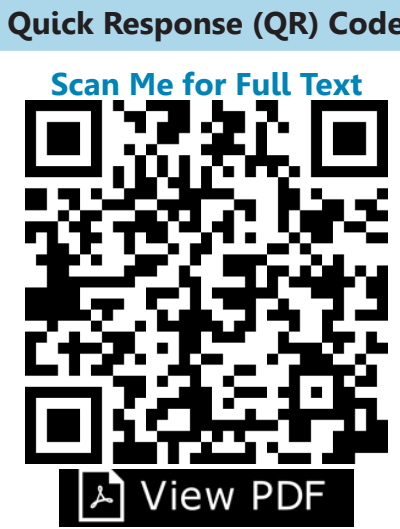

\section{Article Info}

Received: 27 June 2020; Accepted: 7 September 2020; Published Online: 8 September 2020 How to cite this article in Vancouver Style?

Panta PP, Amgain K, Sharma D, Chapagain N, Kafle P. Low Prevalence of Obesity and Pattern of Food Habits among Nepalese Medical Students. Europasian J Med Sci. 2020; 2(2):28-36. https://doi. org/10.46405/ejms.v2i2.173

Conflict of Interest: None Declared;

\section{Disclaimer}

Source of Support: Nil

Copyright: (c) 2020 by author(s). This is an open access article distributed under the terms of the Creative Commons Attribution International License 4.0 (http://creativecommons.org/licenses/ by/4.0/) which permits unrestricted use, distribution, and reproduction in any medium, provided the original work is properly cited.

\section{Publisher's Note}

The Europasian Journal of Medical Sciences (EJMS) (www.europasianjournals.org) is an official Journal of Nirvana Psychosocial Care Center \& Ressearch Institute (www.nirvanapscc.com). The Journal as well as publisher remain neutral with regards to any jurisdictional claims in any published articles, its contents and the institutional affiliations of the authors. 


\section{INTRODUCTION}

Overweight and obesity are major risk factors for several non-communicable diseases(NCDs), such as diabetes, cardiovascular diseases, musculoskeletal disorders, including cancer. The risk for these NCDs increases with increases in BMI. Once considered a problem only in high income countries, obesity has now increased dramatically in low and middleincome countries, particularly in urban settings. According to $\mathrm{WHO}$, worldwide obesity has tripled since 1975. In 2016, 39\% adults of aged 18 years and older were overweight and $13 \%$ were obese. ${ }^{1}$

Obesity is one of the world's largest health problems and the prevalence has increased in the past 50 years, reaching pandemic levels. Obesity has contributed to major risk factors for early death. It was estimated that $8 \%$ of the total deaths were attributed to obesity in 2017. It has become a serious epidemic, estimated to be the fifth leading cause of mortality at a global level. ${ }^{3}$

Obesity among teenagers/adolescents and young adults is associated with significant adverse short and longer-term effects on health. Pattern of food practice and its contribution to the obesity among adolescents and young adults in South Asia region has been changed. ${ }^{4}$

The global prevalence of obesity nearly doubled from $6.4 \%$ in 1980 to $12.0 \%$ in $2008 .{ }^{5}$ At least 35 million overweight children are estimated to be living in developing countries and 8 million in developed countries. ${ }^{6,7}$ Prevalence of overweight and obesity was $4.9 \%$ in 2010 in Asia ${ }^{8}$. Twenty percent of women aged 15-29 years in Nepal are overweight or obese, and correspondingly $15.8 \%$ of the same age group men. ${ }^{9}$ The population of this age group accounts $27.01 \%$ of the total population, which is more than a quarter of the total Nepalese population. ${ }^{10}$

The prevalence of obesity among higher secondary level school adolescents in Kaski district of Nepal was found to be $8.1 \% .{ }^{11}$ One of the major causes of obesity is the changes in the diet, in terms of quantity and quality, which has become more "Westernized".12 These dietary pattern changes were claimed for increasing the prevalence of both overweight and obesity observed among Nepali children, adolescents and young adults in the last few decades. ${ }^{4}$ With the pace of urbanization, development and eating habit, overweight and obesity among adolescents is on increasing trend. It is an epidemic and a public health crisis among adolescents worldwide particularly in developing and low-income countries like Nepal.

Very few research studies have been conducted on overweight and obesity in Nepal so far. Although several nutritional surveys have been conducted, they are unable to assess the prevalence of obesity among adolescents as their focus is on malnourished children. ${ }^{13}$

College students are highly exposed to unhealthy eating habits leading to body weight gain. Studies on college students revealed higher rates of obesity in males than in females. ${ }^{14,15}$ There is lack of sufficient literature regarding obesity prevalence in Nepalese young adult college students. Therefore, the aim of the study was to determine the prevalence of overweight and obesity rates among college students in Nepal and to associate their body weight status and composition with their eating habits.

\section{MATERIALS AND METHODS}

A cross-sectional study was conducted among all of the first and second year MBBS students in Nepal Medical College teaching hospital, Kathmandu Nepal from July 2018 to August 2018, using a self-administered questionnaire. All participants from the first and second year (each year contains 100 participants) were enrolled and consent from students was taken in this study. They were well informed and trained for the proper filling of the questionnaire.

Then the self-administered questionnaires were distributed among all of the 200 participants in their class and only 170 questionnaires were completely filled and the remaining 30 incomplete questionnaires were not included in this study.

For the measurement of height, the stadiometer was used. The Digital weighing machine was used to measure the weight of individual participants, similarly, the systolic and diastolic blood pressure was measured by using the aneroid sphygmomanometer by two medical professionals in two sittings after taking 30 minutes' rest. The average was recorded as the blood pressure reading.

The independent variables were different patterns of food habit and anthropometric measurements including height, weight and blood pressure whereas the dependent variable was BMI. According to $\mathrm{WHO}$ classification, adults were classified based on their $\mathrm{BMI}$ to underweight (BMI < 18.5), normal $(\mathrm{BMI}=18.5-24.9)$, overweight $(\mathrm{BMI}=25-29.9)$, or 
obese (BMI $\geq 30)$.

The Statistical Package for Social Sciences (SPSS Inc., Chicago, IL, USA) version 16 was used for data analysis. The data were presented in percentages, chart, mean and standard deviation as descriptive statistics. A chi-squared test was used to show the association between categorical variables with BMI and t-statistic was applied to test the significant difference of two means between the groups assuming $\mathrm{P}<.05$ for statistical significance.

\section{RESULTS}

Out of 170 participants, more than half of them (54.35\%) were female. About two-third (64.1\%) of the participants were of the age group 19-20 years. Regarding ethnicity, more than half of the participants were Brahmin and Chhetri (57\%), nearly one third (31.25\%) were Newar (Table 1).

By BMI classification, more than three fourth (77\%) among the participants were found to be normal weight. Overweight and obese were represented by $6.5 \%$ and $0.6 \%$ respectively. And $16 \%$ of the students were found to be underweight.

A total of 170 participants, with an average age of $19.91 \pm 1.37$ years, included in the study. The mean weight and height were $57.68 \pm 9.72 \mathrm{~kg}$ and 163.74 $\pm 9.6 \mathrm{~cm}$ respectively. The average $\mathrm{BMI}$, systolic blood pressure (SBP) and diastolic blood pressure $(\mathrm{DBP})$ were $21.46 \pm 2.74,114.34 \pm 8.07 \mathrm{mmHg}$ and $76.75 \pm 6.80 \mathrm{mmHg}$ respectively. An independent t-test was conducted to compare age, weight, height, SBP, DBP and BMI of male and female. There was a statistically significant difference between age, weight, height, SBP, DBP among male and female $(P<.01)$ whereas BMI was not statistically significant $((P>.05)$ (Table 2$)$.

A chi square test of independence was performed to examine the relation between BMI with different demographic variables (sex, age, ethnicity and income of the family). There was no significant association between sex of the students and age with BMI, $\chi_{(2, n=170)}^{2}=4.35, P=.113$ and $\chi_{(2, n}^{2}$ $=170)=4.94, P=.084$ respectively. But a significant association was found between ethnicity and BMI, $\chi_{(2, n=170)}^{2}=10.55, P=.032$; and income of family and $\mathrm{BMI}, \chi_{(2, n=170)}^{2}=6.25, P=.044$ respectively. Brahmin/ Chhetrri by ethnicity were more likely to have obesity than other ethnic groups. Likewise, family income of those students more than 50,000 were more likely to have obesity than the income having less than 50,000 (Table 3)

\begin{tabular}{|c|c|c|c|}
\hline Variables & & No. (n) & Percent \\
\hline \multirow[t]{2}{*}{ Sex } & Male & 77 & 45.7 \\
\hline & Female & 93 & 54.3 \\
\hline \multirow{6}{*}{ Ethnicity } & Brahmin & 57 & 33.5 \\
\hline & Chhettri & 40 & 23.5 \\
\hline & Newar & 53 & 31.2 \\
\hline & $\begin{array}{l}\text { Gurung/ } \\
\text { Magar }\end{array}$ & 5 & 2.9 \\
\hline & $\begin{array}{l}\text { Sherpa/ } \\
\text { Tamang }\end{array}$ & 4 & 2.4 \\
\hline & Other & 11 & 6.5 \\
\hline \multirow{4}{*}{ Age } & $<18$ & 23 & 13.5 \\
\hline & $19-20$ & 92 & 64.1 \\
\hline & $21-22$ & 49 & 28.8 \\
\hline & $>22$ & 6 & 3.5 \\
\hline
\end{tabular}

Regarding the food pattern of students, about three fourth $(72.4 \%)$ of the students reported that they had been taking meals regularly (Table 4). Likewise, most of them (86.5\%) had breakfast daily. Eating snacks was a common habit among participants (88.8\%). The intake of colored vegetables and fruits was common among participants. Two third of the participants $(65.9 \%)$ had consumed colored vegetables (green/yellow/red) regularly. A vast number $(83.3 \%)$ of the participants had eaten fruits daily. More than one quarter participants (27.6\%) consumed fast foods daily.

Regarding the sleeping habit, a vast majority (91.2\%) of the students reported that they slept upto 8 hours, and two-third of them (66\%) were found not involved in the sports or playing whereas $43.5 \%$ participants did exercise regularly. Smoking was not common among participants. A vast majority of the students $(91.2 \%)$ were nonsmokers. However, alcohol consumption was less than fifty percentage $(44.1 \%)$ of total students. About ninety-eight percent of the participants never consumed substance abuse. (Table 4).

A chi square test of independence was calculated comparing the frequency of different food patterns of students in BMI classification. There was no significant association between various food pattern with $\mathrm{BMI}(P>.05)$ (Table 5). 
Table 2 Comparisons of anthropometric measurements of students with sex

\begin{tabular}{|c|c|c|c|c|c|c|}
\hline Variables & Sex & Mean & SD & SE & t-value & P-value \\
\hline \multirow[t]{2}{*}{ Age (yrs.) } & Male & 20.25 & 1.45 & 0.17 & 3.02 & 0.003 \\
\hline & Female & 19.62 & 1.23 & 0.13 & & \\
\hline \multirow[t]{2}{*}{ Weight (Kg) } & Male & 64.36 & 8.88 & 1.01 & 10.45 & $<0.001$ \\
\hline & Female & 52.14 & 6.32 & 0.66 & & \\
\hline \multirow[t]{2}{*}{ Height (Cm) } & Male & 5.729 & 0.22 & 0.02 & 15.55 & $<0.001$ \\
\hline & Female & 5.234 & 0.20 & 0.02 & & \\
\hline \multirow[t]{2}{*}{$\begin{array}{l}\text { Systolic blood pressure } \\
(\mathrm{mm} / \mathrm{Hg})\end{array}$} & Male & 116.53 & 8.85 & 1.01 & 3.31 & 0.001 \\
\hline & Female & 112.53 & 6.90 & 0.72 & & \\
\hline \multirow[t]{2}{*}{$\begin{array}{l}\text { Diastolic blood } \\
\text { pressure }(\mathrm{mm} / \mathrm{Hg})\end{array}$} & Male & 78.47 & 5.89 & 0.67 & 3.06 & 0.002 \\
\hline & Female & 75.33 & 7.20 & 0.75 & & \\
\hline \multirow[t]{2}{*}{$\mathrm{BMI}\left(\mathrm{Kg} / \mathrm{m}^{2}\right)$} & Male & 21.78 & 2.66 & 0.30 & 1.37 & 0.172 \\
\hline & Female & 21.20 & 2.80 & 0.29 & & \\
\hline
\end{tabular}

Table 3: Association between BMI categories and socio-demographic variables

\begin{tabular}{|c|l|c|c|c|c|c|c|}
\hline \multirow{2}{*}{ Variables } & Options & \multicolumn{3}{|c|}{ BMI Categories } & Total & P-value \\
\hline Sex & Male & Underweight & Normal & Overweight/Obese & & \\
\hline & Female & $8(10.4 \%)$ & $65(84.4 \%)$ & $4(5.2 \%)$ & 77 & 4.35 & .113 \\
\hline Age & Below $20 \mathrm{yr}$ & $15(20.0 \%)$ & $52(69.3 \%)$ & $8(10.7 \%)$ & 75 & 4.947 & .084 \\
\hline & $\begin{array}{l}20 \text { years \& } \\
\text { above }\end{array}$ & $12(12.6 \%)$ & $79(83.2 \%)$ & $4(4.2 \%)$ & 95 & & \\
\hline Ethnicity & $\begin{array}{l}\text { Brahmin/ } \\
\text { chhetri }\end{array}$ & $22(22.7 \%)$ & $67(69.1 \%)$ & $8(8.2 \%)$ & 97 & 10.55 & $.032^{*}$ \\
\hline & Janajati & $3(4.8 \%)$ & $55(88.7 \%)$ & $4(6.5 \%)$ & 62 & & \\
\hline $\begin{array}{l}\text { Income of } \\
\text { the family }\end{array}$ & Others & $2(18.2 \%)$ & $9(81.8 \%)$ & $0(0 \%)$ & 11 & & \\
\hline
\end{tabular}




\begin{tabular}{|c|c|c|c|}
\hline Question Asked & Options & Number & Percentage \\
\hline \multirow[t]{2}{*}{ Taking meals } & Always regular & 123 & 72.4 \\
\hline & Irregular & 47 & 27.6 \\
\hline \multirow[t]{2}{*}{ Taking Breakfast } & Daily/Regular & 147 & 86.5 \\
\hline & Irregular & 23 & 13.5 \\
\hline \multirow[t]{3}{*}{$\begin{array}{l}\text { Taking snacks apart from regular } \\
\text { meals }\end{array}$} & Daily & 151 & 88.8 \\
\hline & Three or four time per week & 16 & 9.4 \\
\hline & Rarely & 3 & 1.8 \\
\hline \multirow[t]{2}{*}{$\begin{array}{l}\text { Eating vegetables(green/red/ } \\
\text { yellow) }\end{array}$} & Regularly(daily) & 112 & 65.9 \\
\hline & Irregularly & 58 & 34.1 \\
\hline \multirow[t]{2}{*}{ Eating fruits } & Daily & 142 & 83.5 \\
\hline & Rarely & 28 & 16.5 \\
\hline \multirow[t]{3}{*}{ Eating fast food } & Daily & 47 & 27.6 \\
\hline & Sometimes & 109 & 64.1 \\
\hline & Very rarely & 14 & 8.2 \\
\hline \multirow[t]{3}{*}{ Sleeping hours } & Less than 6 hours & 18 & 10.6 \\
\hline & $6-8$ hours & 137 & 80.6 \\
\hline & more than 8 hours & 15 & 8.8 \\
\hline \multirow[t]{2}{*}{ Participation in playing/sports } & Yes & 58 & 34.1 \\
\hline & No & 112 & 65.9 \\
\hline \multirow[t]{4}{*}{ Smoking history } & Current smoker & 2 & 1.2 \\
\hline & Ex-smoker & 10 & 5.9 \\
\hline & Occasional smoker & 3 & 1.8 \\
\hline & Never smoker & 155 & 91.2 \\
\hline \multirow[t]{2}{*}{ History of alcohol } & Yes & 75 & 44.1 \\
\hline & No & 95 & 55.9 \\
\hline \multirow[t]{3}{*}{ Habits of taking alcohol $(n=75)$} & Regularly & 1 & 1.3 \\
\hline & Sometimes & 9 & 12.0 \\
\hline & Occasional social drink & 65 & 86.7 \\
\hline \multirow[t]{2}{*}{ Substance/drug consumption } & Yes & 3 & 1.8 \\
\hline & No & 167 & 98.2 \\
\hline \multirow[t]{2}{*}{ Exercise } & Yes & 74 & 43.5 \\
\hline & No & 96 & 56.5 \\
\hline
\end{tabular}




\begin{tabular}{|c|c|c|c|c|c|c|c|}
\hline \multirow[t]{2}{*}{ Variables } & \multirow[b]{2}{*}{ Options } & \multicolumn{3}{|c|}{ BMI Categories } & \multirow[t]{2}{*}{ Total } & \multirow{2}{*}{ value } & \multirow{2}{*}{$\begin{array}{l}P \\
\text { value }\end{array}$} \\
\hline & & & Normal & $\begin{array}{l}\text { Overweight } \\
\text { and obese }\end{array}$ & & & \\
\hline \multirow[t]{2}{*}{$\begin{array}{l}\text { Taking meal } \\
\text { regularly }\end{array}$} & Always regular & $20(16.3 \%)$ & $95(77.2 \%)$ & $8(6.5 \%)$ & 123 & .236 & .889 \\
\hline & Trregular & $7(14.9 \%)$ & $36(76.6 \%)$ & $4(8.5 \%)$ & 47 & & \\
\hline \multirow[t]{2}{*}{$\begin{array}{l}\text { Taking } \\
\text { breakfast }\end{array}$} & Daily & $26(17.7 \%)$ & 111(77.5\%) & 10(6.8\%) & 147 & 2.66 & .264 \\
\hline & Irregularly & $1(4.3 \%)$ & $20(87.0 \%)$ & $2(8.7 \%)$ & 23 & & \\
\hline \multirow[t]{4}{*}{$\begin{array}{l}\text { Taking snacks } \\
\text { apart from } \\
\text { meal }\end{array}$} & One time & 15(16.7\%) & $68(76.6 \%)$ & $7(7.8 \%)$ & 90 & 8.33 & .215 \\
\hline & Two time & $7(11.5 \%)$ & $51(83.6 \%)$ & $3(4.9 \%)$ & 61 & & \\
\hline & 3 or 4 time/week & $3(18.8 \%)$ & $11(68.8 \%)$ & $2(12.5 \%)$ & 16 & & \\
\hline & Rarely & $2(66.7 \%)$ & $1(33.3 \%)$ & $0(0.0 \%)$ & 3 & & \\
\hline \multirow[t]{2}{*}{$\begin{array}{l}\text { Eating } \\
\text { vegetables }\end{array}$} & Regularly (Daily) & $21(18.8 \%)$ & $82(73.2 \%)$ & $9(8.0 \%)$ & 112 & 2.77 & .250 \\
\hline & Irregularly & $6(10.3 \%)$ & $49(84.5 \%)$ & $3(5.2 \%)$ & 58 & & \\
\hline \multirow[t]{2}{*}{ Eating fruits } & Daily & $23(16.2 \%)$ & $110(77.5 \%)$ & $9(6.3 \%)$ & 142 & .707 & .702 \\
\hline & Rarely & $4(14.3 \%)$ & $21(75.0 \%)$ & $3(10.7 \%)$ & 28 & & \\
\hline \multirow[t]{3}{*}{$\begin{array}{l}\text { Eating fast } \\
\text { food }\end{array}$} & Daily & $8(17.0 \%)$ & $35(74.5 \%)$ & $4(8.5 \%)$ & 47 & 1.010 & .908 \\
\hline & Sometimes & $16(14.7 \%)$ & $86(78.9 \%)$ & $7(6.4 \%)$ & 109 & & \\
\hline & Very rarely & $3(21.4 \%)$ & $10(71.4 \%)$ & $1(7.1 \%)$ & 14 & & \\
\hline \multirow[t]{4}{*}{$\begin{array}{l}\text { Smoking } \\
\text { status }\end{array}$} & Current smoker & $0(0 \%)$ & $2(100.0 \%)$ & $0(0 \%)$ & 2 & 1.78 & .938 \\
\hline & Ex-smoker & $1(10.0 \%)$ & $8(80.0 \%)$ & $1(10.0 \%)$ & 10 & & \\
\hline & $\begin{array}{l}\text { Occas ion a I } \\
\text { smoker }\end{array}$ & 1(33.3\%) & $2(66.7 \%)$ & $0(0 \%)$ & 3 & & \\
\hline & Never smoker & $25(16.1 \%)$ & 119(76.8\%) & $11(7.1 \%)$ & 155 & & \\
\hline \multirow[t]{2}{*}{$\begin{array}{l}\text { Ever drink } \\
\text { alcohol }\end{array}$} & Yes & $9(12.0 \%)$ & $59(78.7 \%)$ & 7(9.3\%) & 75 & 2.3 & .316 \\
\hline & No & $18(18.9 \%)$ & $72(75.8 \%)$ & $5(5.3 \%)$ & 95 & & \\
\hline \multirow[t]{3}{*}{$\begin{array}{l}\text { Sleeping } \\
\text { hours }\end{array}$} & Less than 6 hrs. & $4(22.2 \%)$ & $12(66.7 \%)$ & $2(11.1 \%)$ & 18 & 1.56 & .816 \\
\hline & 6 hours & $20(14.6 \%)$ & 108(78.8\%) & $9(6.6 \%)$ & 137 & & \\
\hline & More than 6 hrs. & $3(20.0 \%)$ & $11(73.3 \%)$ & $1(6.7 \%)$ & 15 & & \\
\hline \multirow[t]{2}{*}{$\begin{array}{l}\text { Tnvolved in } \\
\text { sports }\end{array}$} & Yes & $9(15.5 \%)$ & 47(81.0\%) & $2(3.4 \%)$ & 58 & 1.81 & .404 \\
\hline & No & $18(16.1 \%)$ & $84(75.0 \%)$ & $10(8.9 \%)$ & 112 & & \\
\hline
\end{tabular}




\section{DISCUSSION}

The purpose of this study was to assess the prevalence of obesity, examine patterns of food habits and to correlate their body weight status with their eating habits. Body mass index(BMI) was used to assess weight status of the participants. Based on the BMI classification of weight status, the findings of this study indicates that more than two-third of students were of normal weight (77.1\%). This study showed that the prevalence of obesity of the students was $7.1 \%$ of the students. These findings are supported by a study conducted in Kaski district by Acharya et.al. The prevalence of overweight and obesity among higher secondary level school adolescents in Kaski district was found to be $8.1 \%$, of which $5.8 \%$ were overweight and $2.3 \%$ were obese. ${ }^{11}$ Another study has also revealed the prevalence of overweight of Nepalese young adults to be $7.9 \%{ }^{4}$

Nepal demographic Health Survey (NDHS) had also shown comparable occurrence of normal weight (66\% in male and $68 \%$ in female) as evident in our study. However, the prevalence of overweight and obesity was higher than our study population. ${ }^{9}$

In contrast, the study conducted in Lebanon showed the higher prevalence of overweight and obesity among male college students to be $37.5 \%$ and $12.5 \%$, respectively than our study. ${ }^{15}$ Likewise, in a study conducted in Kuwait the corresponding percentages were $32 \%$ and $8.9 \%{ }^{16}$, while in the United Arab Emirates overweight and obese accounted for about $35 \%$ of the male college students. ${ }^{17}$ Similarly, the study in Saudi Arabia revealed the prevalence of overweight and obesity to be $21.8 \%$ and $15.7 \%$ respectively. ${ }^{18} \mathrm{~A}$ study conducted among medical students in Malaysia showed twice (14.8\%) the prevalence of this study. ${ }^{19}$ Our findings were greatly supported by the study conducted in Iranian male college which showed $7.9 \%$ of students were above the normal body weight. ${ }^{20}$ The finding of this study is in the line of the study done in Chinese university students, which showed $2.9 \%$ were obese and $80.5 \%$ were normal by body weight. ${ }^{21}$

The results of our study showed that most of the participants have regular meals (72.4\%), twothird of the participants ate vegetables regularly $(66.0 \%)$ and the vast majority (83.5\%) of the total participants ate fruits at least once a day. Talking about snacks, the vast majority (88.8\%) of the total participants eat snacks at least once. But their habit of taking fast food daily is just one in four participants (27.6\%). Comparing our results with equivalent studies from Lebanon and China ${ }^{15,21}$, for a similar setting, revealed the same kind of result regarding eating habits. Most of the Nepalese students $(72.4 \%)$ eat a regular meal which is slightly higher than Lebanon (61.4\%) and slightly lesser than China (83.6\%). But there is a diverse result found in Saudi Arabia where only $36.7 \%$ of total participants reported consumption of meal regularly. ${ }^{18}$

The vast majority (86.5\%) of Nepalese students have breakfast daily which resembles the findings in China (82.3\%). Whereas in Saudi Arabia and Lebanon, almost half of the students $(49.9 \%$ and $52.1 \%$ respectively) eat breakfast. ${ }^{21,22}$ The higher proportion of taking breakfast in Nepalese students may be due to the class schedule of 9am to 4 pm. Eating snacks was a common habit among Nepalese students and its daily consumption was reported in $52.9 \%$ of them, whereas it was found one third in Arabia and only $10 \%$ in china. ${ }^{20}$

Vegetables and fruits consumption was a common habit among Nepalese students. Among the participants, two-third consumed vegetables and the vast majority $(83.5 \%)$ consumed fruits at least once a day. On the other hand, less than half (47.9\%) of the Chinese students consumed colored vegetables and one-third reported consumption of fruits daily. ${ }^{21}$ Likewise, $56.3 \%$ of Lebanese students consumed vegetables and $49 \%$ fruits at the same rate..$^{15}$ The diverse result is found in Saudi, in which one in ten consumed colored vegetables daily and very few of them $(4.5 \%)$ ate fruits daily. ${ }^{18}$ The obesity of Nepal is comparatively low than in other countries. It may be attributed to the fiber diet, such as vegetables and fruits.

It is found that $91.2 \%$ of the total students were nonsmokers and $55.9 \%$ of them never drank alcohol. This result validates the findings of a study conducted in Saudi Arabia where 86.8\% were nonsmokers but the varied result was found in alcohol consumption where $95.8 \%$ never drank alcohol $^{18}$. Alcohol and smoking were not common in Lebanon. ${ }^{15}$ Another study conducted in China supports our study where current tobacco users were $6.9 \%$ and alcohol $38.9 \% .{ }^{21}$

Regarding sleeping hours, this study revealed that $10.6 \%$ slept less than 6 hours, $80.6 \%$ slept $6-8$ hours and $8.8 \%$ for more than 8 hours. The similar findings were found in the study conducted by Supa Pengpid et al. ${ }^{22}$ where more than half (55\%) of the students used to sleep for $7-8$ hours, $30.6 \%$ for 6 hours or less and $14.4 \%$ for 9 hours or more. 
As found in some other studies, this study showed an insignificant $(P>0.05)$ association between BMI and eating habits. It means that obesity does not depend on eating habit. ${ }^{15,18}$ The variables of eating habits were the consumption of vegetables, fruits, breakfast, snacks, smoking habit and consumption of alcohol. None of the variables were significantly associated with BMI of the students. However, ethnicity and family income were significantly associated with the BMl of the participants $(P<.05)$. But other demographic variables such as age and sex were not significantly associated with $\mathrm{BMI}(P>$ .05). A study conducted in India showed a significant association between high socioeconomic status and eating fruits to the BMl of students, but did not find the association between age and ethnicity ${ }^{23-25}$. Regarding age, sex and smoking habit, there was no significant association whereas an association was seen in other studies. ${ }^{21}$

The study was conducted among the students of the Nepal Medical College. So the finding of this study might not represent the general population. In other hand, the self-administered questionnaire used to collect the data in this study might not be responded properly.

\section{CONCLUSION}

The prevalence of obesity was found to be lower in comparison to national scenarios as the healthy food habits were predominant among the medical students. The pattern of taking a regular meal, and breakfast with the adequate vegetables, and fruits, avoiding use of alcohol and smoking, along with regular exercise and sleeping time of 6-8 hours were the predominant behaviors of medical students.

\section{REFERENCES}

1. World Health Organization: WHO. Obesity and overweight. Who.int. World Health Organization: WHO; 2020 [Accessed on 2020 Aug 19]. [Full Text]

2. Ritchie H, Roser M. Obesity. Our World in Data, 2018 [cited 2020 Aug 20]. Available from: https:// ourworldindata.org/obesity [Full Text]

3. Ezzati M, Organització Mundial de la Salut. Comparative quantification of health risks: global and regional burden of disease attributable to selected major risk factors. Geneva: World Health Organization; 2004. [Google Scholar] [Full Text]

4. Jayawardena $R$, Ranasinghe $P$, Wijayabandara $M$, Hills AP, Misra A. Nutrition Transition and Obesity Among Teenagers and Young Adults in South Asia. Bentham Science Publishers; 2017. [Google Scholar] [CrossRef] [Full Text]
5. Stevens GA, Singh GM, Lu Y, Danaei G, Lin JK, Finucane MM, et al. National, regional, and global trends in adult overweight and obesity prevalences. Popul Health Metr. 2012; 20:10-22. [Google Scholar] [PubMed] [CrossRef] [Full Text]

6. $\mathrm{PMNCH} \mid \mathrm{PMNCH}$ Knowledge Summary \#18 Nutrition [Internet]. WHO. World Health Organization; [Accessed on 2020 Apr 7]. [Google Scholar] [Full Text]

7. WHO | Childhood overweight and obesity. WHO. World Health Organization; [Accessed on 2020 Apr 7]. [Full Text]

8. Balarajan $Y$, Villamor E. Nationally representative surveys show recent increases in the prevalence of overweight and obesity among women of reproductive age in Bangladesh, Nepal, and India. J Nutr. 2009; 139(11):2139-44. [Google Scholar] [PubMed] [CrossRef] [Full Text]

9. Nepal-Demographic-Health-Survey-NDHS-2016Final-Report.pdf [Internet]. Google Docs. [Accessed on 2020 Apr 8].[Full Text]

10. Demographics of Nepal. In: Wikipedia [Internet]. 2020 [Accessed on 2020 Apr 8]. [Link]

11. Acharya B, Chauhan HS, Thapa SB, Kaphle HP, Malla D. Prevalence and socio-demographic factors associated with overweight and obesity among adolescents in Kaski district, Nepal. Indian Journal of Community Health. 2014;31;26 (Supp 2):118-22. [Google Scholar] [Full Text]

12. Gasbarrini A, Piscaglia AC. A natural diet versus modern Western diets? A new approach to prevent "well-being syndromes." Dig Dis Sci. 2005;50(1):1-6. [Google Scholar] [PubMed] [Full Text]

13. Aryal M. Childhood Obesity, Unrecognized public health challenge in Nepal. Kathmandu University Medical Journal. 2010;8(4):358-9. [Google Scholar] [CrossRef] [Full Text]

14. Huang TT, Harris KJ, Lee RE, Nazir N, Born W, Kaur $\mathrm{H}$. Assessing overweight, obesity, diet, and physical activity in college participants. Journal of American College Health. 2003;52(2):83-6. [Google Scholar] [PubMed] [CrossRef]

15. Yahia N, Achkar A, Abdallah A, Rizk S. Eating habits and obesity among Lebanese university participants. Nutrition journal. 2008;7(1):32. [Google Scholar] [CrossRef] [BMC] [Full Text]

16. Al-Isa AN. Obesity among Kuwait University participants: an explorative study. The journal of the Royal Society for the Promotion of Health. 1999;119(4):223. [Google Scholar] [PubMed] [CrossRef] [Full Text]

17. Musaiger AO, Lloyd OL, Al-Neyadi SM, Bener AB. Lifestyle factors associated with obesity among male university participants in the United Arab Emirates. 
Nutrition \& Food Science. 2003.[Google Scholar] [CrossRef] [Full Text]

18. Al-Rethaiaa AS, Fahmy A-EA, Al-Shwaiyat NM. Obesity and eating habits among college participants in Saudi Arabia: a cross sectional study. Nutrition journal. 2010;9(1):39. [Google Scholar] [PubMed] [CrossRef] [BMC] [Full Text]

19. Gopalakrishnan S, Ganeshkumar P, Prakash MVS, Christopher N, Amalraj V. Prevalence of overweight/ obesity among the medical participants, Malaysia. Med J Malaysia. 2012;67(4):442-4. [Google Scholar] [PubMed] [Full Text]

20. Nojomi M, Najamabadi S. Obesity among university participants, Tehran, Iran. Asia Pacific journal of clinical nutrition. 2006;15(4):516-20. [Google Scholar] [PubMed] [Full Text]

21. Sakamaki R, Toyama K, Amamoto R, Liu CJ, Shinfuku $\mathrm{N}$. Nutritional knowledge, food habits and health attitude of Chinese university participants-a cross sectional study-. Nutrition journal. 2005;4(1):4. [Google Scholar] [PubMed] [CrossRef] [BMC] [Full Text]
22. Pengpid S, Peltzer K. Prevalence of overweight/ obesity and central obesity and its associated factors among a sample of university participants in India. Obesity Research \& Clinical Practice. 2014;8(6):e55870. [Google Scholar] [PubMed] [CrossRef] [BMC] [Full Text]

23. Piryani S, Baral KP, Pradhan B, Poudyal AK, Piryani RM. Overweight and its associated risk factors among urban school adolescents in Nepal: a crosssectional study. BMJ Open. 2016;6(5):e010335. [Google Scholar] [PubMed] [CrossRef] [PMC] [Full Text]

24. Fernandez K, Singru SA, Kshirsagar $M$, Pathan Y. Study regarding overweight/obesity among medical participants of a teaching hospital in Pune, India. Medical Journal of Dr. DY Patil University. 2014;7(3):279. [Google Scholar] [CrossRef] [Full Text]

25. Amgain K, Neupane S. Effects of Food Habits on Menstrual Cycle among Adolescent Girls . Europasian J Med Sci. 2019; 1(1):53-9. https://doi.org/10.46405/ ejms.v1i1.35 [Full Text] 